\title{
Notices of Wroxeter, the Roman Urioconium, in Shropshire
}

\author{
the Rev Harry. M. Scarth M.A.
}

To cite this article: the Rev Harry. M. Scarth M.A. (1859) Notices of Wroxeter, the Roman Urioconium, in Shropshire, Archaeological Journal, 16:1, 53-70, DOI: 10.1080/00665983.1859.10851106

To link to this article: http://dx.doi.org/10.1080/00665983.1859.10851106

里 Published online: 10 Jul 2014.

Submit your article to this journal $₫$

Џll Article views: 1

Q View related articles 5 
NOTICES OF WROXETER, THE ROMAN URIOCONIOM, IN SHROPSHIRE.

BY THE REV. HARRY. M. SCARTH, M.A.

THE increasing interest with which the traces of the Roman occupation of Britain are regarded, and more especially the praiseworthy efforts recently made to rescue from oblivion the neglected vestiges of the great Roman city of the Welsh Marches, URIoconium, have encouraged the hope that, on the eve of a systematic exploration of its extensive remains, some detailed notice of its position and history, as also of the relics of Roman times heretofore discovered, may not be unacceptable to the readers of this Journal. Some of them, doubtless, are already familiar with the interest and striking position of Wroxeter, which was visited during the meeting of the Institute in Shrewsbury, in 1855. In the following memoir will be found the substance of the communication prepared for that occasion, and I have endeavoured to combine, with the results of personal observation, all facts of importance hitherto recorded, and scattered notices by various writers who have treated of the antiquities of a locality, which for some years I have regarded as fraught with peculiar interest. Among those who hare directed their attention to the Roman remains at Wroxeter, I would specially acknowledge the assistance which I have derived from the account given by the Rev. C. H. Hartshorne in the Salopia Antiqua. I have been much indebted to a MS. account of Wroxeter, illustrated by drawings of the remains found at various times, compiled by the late Mr. Farmer Dukes, of Shrewsbury, and by him presented to the Society of Antiquaries of London; through their courtesy I have been allowed access to these collections. The late Rev. J. B. Blakeway, the historian of Shrewsbury, had collected many MS. notes on Wroxeter, which were left by him to the Bodleian Library. Through the kindness of a member of the Institute I have obtained a copy of these valuable documents, my attention having been first directed to them by the historian of Shropshire, the 
Rev. R. Wynne Eyton. Much information is contained in the Philosophical Transactions and in the Archæologia, which has for the most part been carefully brought together by the writers I have mentioned. I would also acknowledge the assistance I have received from Mr. Pidgeon of Shrewshury, who has kindly given me information, and who has devoted a fer pages of his "Memorials of Shrewsbury" to examine into the history of Wroxeter, regarding it, with Horsley, as the origin of the town of Shrewsbury.

If we would search into the origin of Wroxeter, we must turn our attention to the neighbouring mountain, and we shall find that the camp on the Wrekin is much anterior, and in all probability may be regarded as the origin of the Roman city of Urioconium. The form of this encampment has been thus described by Mr. Hartshorne. On ascending from the east, a ditch is crossed near the summit, which following the course of the eminence, runs distinctly visible from N.E. to S.S.W. for 50 paces. The fosse is very narrow, and does not seem, when in its most perfect state, ever to have been deep; its present width is scarcely 3 yards. Below this rampart was formerly another, which is now in great measure obliterated; it was once much more distinct. This camp has been assigned to the period of Caractacus. The gate of entrance at the north end is called Heaven-gate, and the fall on the north-east, although very precipitous, is strengthened by a ditch, which may be discerned for 30 or 40 yards. The width of the portals or sides of this gate, is about 6 feet. At the top of a ridge within the camp there is a tumulus ${ }^{1}$ about 4 feet high, 16 paces across its crest, with a slight indentation in the middle. About 40 paces further is another gate of entrance, the portals of which have an oblong form ; they are 25 yards long and 12 across, but the same distance asunder. These are called Hell-gate. ${ }^{2}$

Various derivations have been given for the name Wrekin. The Celtic Bre, synonymous with Vie or Wre signifies a hill, and ken, the chief or principal. Wre-ken

1 I cannot but regard this tumulus as the remains of a beacon, used no doubt in the earliest tímes to communicate signals to the camps within sight. The Romans, after they becamo possessed of this camp, no doubt used it for a similar purpose, and it would serve as an outpost for defence of the city on the enstern side from whence it commanded a view of the course of the long line. of the Watling street road which passed close under it.

2 Hartshorne's Salopia Antiqua, p. 89. 
may therefore signify the chief or conspicuous hill. Llywarc Hen calls it Ddinlle Vrecon, or the high-placed city of Wrecon. ${ }^{3} \quad$ The name has also been derived from the Gaelic Braighe, pronounced and written Bre and Bri, a hill, and $I n$, land - the Hill or Headland.

Nennius mentions Caer Urnach, which has generally been considered to mean Wroxeter ; and Baxter has conjectured that Urnach was abbreviated from Uar na üag, ad cervicem fuctus. 'This subject has been fully discussed by Mr. Hartshorne, and we refer our readers to his work, where these and other etymological speculations on this difficult question are set forth. It may suffice here to remark that the name may be derived according to these learned arguments either from the mountain or from the junction of the two rivers, on which the city has stood. Both derivations describe its position. I should certainly, however, prefer the former, the mountain being the most remarkable feature ; and, moreover, the former is not peculiar, for if we examine the position of Roman stations in this Island and elsewhere, we find them commonly placed at the confluence of rivers.

The settlement of the Station of Urioconium is involved in obscurity. It is probable that it originated in the campaign of Ostorius against Caractacus, whose memory is preserved in one of the hills which forms a most picturesque feature in the view from Wroxeter. On the Caer Caradoc, one of the heights to the south-west, is situated a camp ascribed to Caractacus, and supposed to be near the scene of the battle described by Tacitus, which ended in the entire defeat of that chief, The Breidden, however, seems to present a better claim to that honour.

The hill-fortresses are the earliest vestiges which we possess of the ancient inhabitants of this island, and these were no sooner taken possession of by their Roman conquerors, than they selected an eligible site for their fortified station or city, generally not far distant from the British settlement. This I have remarked in Somersetshire. In the neighbourhood of Bath there are the traces of an ancient British settlement on Hampton Down, one of the

3 The words of Llywarch are-_" I have gazed on the vale of Freuer from Ddinllo Vrecon," which is translated the "hirg placed city of the Wrekin.' This derivation of Urioconium will appear more pro. bable when we consider the name Wroc. wardine, a village on the opposite side of the mountain, which may be conceived to derive its name from Wrekin Worthen, "the village of the Wrekin." 
hills immediately overhanging the present city, and on the opposite hill are the remains of a Roman camp, established, before the valley below, where the hot springs rise, became occupied, and formed the foundation of the present city of Bath.

If we consider the situation of Urioconium, we perceive that it is admirably chosen for security, as well as placed in a fertile district, remarkable for its salubrity. Urioconium was situated on the borders of the Cornavii, on the boundary between them and the Ordorices. The camp on the Wrekin seems to have been a border fortress or fastness of the Cornavii, and the Roman fortified city of Urioconium which succeeded possessed great advantages as a military station; on two sides it is protected by the deep and rapid rivers, the Severn and the Tern, which have their junction near the city. The Wrekin, which rises 1370 feet above the level of the plain, is situated on the eastern side, between the Severn and the Watling Street, and about three miles distant, affording a good point of observation. From the top of this mountain the surrounding country is visible to a distance of seventy-five miles, and thus signals could be conveyed for a great distance by means of fire. The adjoining district is abundantly intersected by large streams, and anciently abounded in extensire meres or pools, many of them being some miles in circumference. The river Tern rises at Mere Pool in the county of Stafford, and flows through a country abounding with marshes and peat lands, which are soft and dangerous, and difficult to pass over.

The northern and north-west portion of the county extending to the confines of Wales, and towards Cheshire and Staffordshire, is still full of morasses, notwithstanding the improvements which have taken place in draining the country since the Norman conquest. This must have rendered it nearly impenetrable in the early period of the Roman occupation. It was, moreover, the point from whence the still unsubdued inhabitants of North Wales might be held in check; the city may indeed have originated in a eamp formed as a basis of operations against the Britons who had retreated to that remote part of the island. ${ }^{4}$

4 Dr. Harwood, Phil. Tr., No. 306 ,
conjectures that Wroreter was founded
by Suetonius or Agricola in the march to subdue Mona. By the circumstance of Urioconium being placed on the eastern bank of the Severn, it should appear that 
The first writer of antiquity by whom Wroxeter is mentioned is Ptolemy, who speaks of Oiıpoкovioy as one of the chief cities of the Cornavii. This name is found in the Itinerary of Antoninus under the Latinised form URIOCONIUM ; and, according to the doubtful authority of Richard of Cirencester, Uriconium (sic), which he calls also Virioconium, was one of the largest cities in Britain. ${ }^{5}$ In the second Iter of Antoninus, it is placed between Rutunium and Usacona, and, as Mr. Hartshorne observes, the distance between Rowton Castle and Oaken Gates (where an Hypocaust has been found), exactly corresponds with the numbers of the Itinerary.

Horsley, in his Britannia Romana, published in 1732, thus speaks of Wroxeter: "Urioconium, 11 miles in the Itinerary of Antonine from Rutunium (Rowton), has with good reason been fixed at Wroxeter. I spent the greatest part of a day with much pleasure, in viewing that place and the antiquities of it. . . . The town has been rery large, and also the fortified ground. It is situated on the north or northeast side of the Severn, and on the other side of the place runs a small rivulet; so that this (as many other Roman stations) has been situated on a lingula, near the confluence of a rivulet and a larger river. There is a piece of old wall yet standing, which has in it three regular strata of Roman brick, each stratum consisting of the thickness of two bricks. It is about 8 yards high, and about 20 yards long. The field this stands in. I thought to be the pratorium; for like Aldborough in Yorkshire, the whole city seems to have been encompassed with a rampart and ditch, above half a mile square, the vestiges of which may still be discerned. . . . Shrewsbury, which is a large pleasant town, has probably arose out of the ruins of Urioconium, from which it is three miles distant. Here again the way divides into two, forming the usual angle. One branch goes towards the Strettons, and so into Herefordshire, which is also called Watling Street; the other branch goes into Staffordshire."

This passage has been often quoted, and it might have been thought superfluous here to repeat it, were it not for a

those parts of Shropshire which lay to the west of that river were still in the hands of the Britons. Sce Blileway's MS., Bod. Lib., Ox.
5 Ric. Corineusis do situ Brit., lib. i. c. 27 .

- Britanuia Romana, p. 419, book iii. cb. ii. Essay on Antonine's Itinerary of Britain. 
MS. note from the pen of that learned antiquary, the Rev. T. Leman, which is worth preserving. He says, "I do not understand what Horsley means by the way at this place dividing into two, for besides the north-east Watling-Street, which passed through it from Caer Segont to Richborough, there were great roads branching from it in every direction to Caerleon, to Chester, to Kinderton, to Chesterton, and towards Worcester." Mr. Leman also observes that Viroconium was the capital of the Cornavii, and stood on the Great British trackway, the Watling Street. He conceives the Roman roads to have been formed on the lines of British Trackways previously existing.

The soil immediately within part of the limits of the ancient city is of a black colour, and remarkable for its fertility. This was attributed to its having been burned. The fact that the city suffered more than one conflagration can scarcely be questioned. The remains of burned matter, of which more than one layer has been found, appear to prove the fact, but that such conflagration should cause the general blackness of the soil may appear questionable. I believe that in most places where a Roman town has existed, the ground on which it stood can be distinguished by its dark colour. This notion, however, prevailed so long ago as 1701, when Mr. Lyster wrote his account of a Sudatory found at Urioconium.

It has been supposed from the Saxon name, Wreaken Ceaster, that the Saxon invaders found the city in ruin when they settled in this part of the island, as if that word denoted the wrecked city. This name, however, probably signifies only the City of the Wrekin, the Saxon name corresponding to that of the Roman, and each indicating the city, from the name of the contiguous mountain. In the absence of any historical evidence, it is impossible to decide whether it was ruined by accidental fire, by the inroads of the Picts before the arrival of the Saxons, or, as appears most probable, by some irruption from the inhabitants of North Wales.

$i$ It seems scarcely needful to advert to the iron seal found at Wroxeter, doscribed by Baxter in his Glossary, under Veroconium, p. 243, and cited on his authority by Mr. Blakeway, as a proof that Wroxeter was not destroyed by the Saxons. Baxter conjectured, that it might have belonged to Offa, king of
Melcia, but no argument can be grounded on this relic, which represented a regulus, or petty prince, crowned, with the legend, CAPVT SElrVi Der. An impression of the seal was seut to Mr. Blakeway by the Vicar, the Rev. T. Markham. See Phil. Trans., No. 309. 
Mr. Blakeway observes that the city had probably been abandoned as a military station by the Romans, together with other internal stations of the island, before the time of the second Theodosius, A.D. 450, as no mention of it occurs in the Notitia a few years earlier. Mr. Lloyd (MS. Hist. of Shropshire, p. 24) fixes its ruin between 520 and 594. If it had continued to the time of Danish invasions, some Saxon relics, Mr. Blakeway supposes, might doubtless have been found, as well as Roman antiquities which are very numerous. Mr. Blakeway observes that the conjecture of Baxter that it continued "pene ad octavum seculum" is founded upon two words of the geographer of Ravenna, who lived in the tenth century. He considers that the notion of its having been the head city of the Cornavii, and afterwards the royal seat of the Mercians, is wholly untenable ; and in conclusion he sums up his investigation thus:-That the place was Roman, and was deserted by that people before the completion of the Notitia, (circiter 445): (for other'wise would it not have been included in that document?) That it was afterwards inhabited by the British who were Christians, till its demolition, which did not probably take place till after the days of Llywarch Hen, (circiter 590) but that soon after that period it was reduced to ashes, either by the North Welsh or Saxons. ${ }^{8}$

The extent of the circumference of Urioconium was not less than three miles, and it contained an area of from 300 to 400 acres. A vallum and fosse, still discernible, encircled the whole. Mr. Hartshorne has given an account of the boundary, and to his work I must refer for a minute description. ${ }^{9}$. The road leading from the Horse Shoes Inn, now a mere lane, may be regarded as the line of the ancient Watling Street, leading into the city on the east side, and outside the gate in that direction was the burying ground of the

$s$ In the late Mr. Kemble's invaluable work, the Codex Diplom. Avi Sax., tom. ii. p. 58, No. cclexvii, there is a charter of Burgred of Mercia, A. D. 855, containing the following passage:-" It illam terram III. manentium in Beonetlege in occidentale plaga Saebriue etiam liberabo a pascua porcorum regis quod nominamus Fearnlesuue ..... Gesta est autem hujus libertatis donatum anno dice Incarnationis DCCCLV ${ }^{\circ}$. iudictione $I^{n}$. in loco qui rocatur Osuualdesdun,

VOL. XVI. quando fuerunt pagani in Uureocensetuv." It has been suggested that Uureoeensetun, which is here mentioned as in the hands of the Pagans, i.e., the Danes, may havo been identical with Urioconium. If this be admitted, this charter would bring the existence of that city down to the year 855 ; and this, it must be observed, agrees with the account of the geographer of Ravenna.

9 Salopia Antiqua, p. 128. 
city, as indicated by the four sepulchral monuments which were found in 1752 about half a mile from the circuit of the wall. A small rivulet called Bell Brook passes through the northern portion of the city. ${ }^{1}$

The most prominent feature of the ancient city is the "Old Wall," which stands in a field adjoining the road which leads from Build was to Shrewsbury. This is a remarkable example of Roman masonry. It has been carefully described by Mr. Hartshorne with an accurate representation of its peculiar construction. Mr. Carte of Leicester, in 1721, appear's to have been the first who called the attention of antiquaries to this interesting specimen of Roman masonry. When Mr. Lloyd made his collections for a history of the county, it was 20 feet high and 100 feet long. Horsley has left a concise description of it. He gives the dimensions as almost eight yards high, twenty long, and he adds, - " the field this stands in I thought to be the prcetorium." It is difficult to conjecture the purposes of this building. Baxter supposed it was a bath, an opinion to which he was led by the discovery of a Hypocaust in its immediate vicinity. I confess that, in examining the remains of the ancient Roman baths at Treves, I was much struck by the similarity of the appearance of the masonry. It may, however, have formed a portion of the public granary, or have been a Basilica. With respect to the probable date of this building; a discovery occurred in 1841, since the publication of Mr. Hartshorne's work, by which an approximation may possibly be made to the date of the erection. A large brass coin of Trajan is said to have been found embedded in the mortar of the "Old Wall." Hence, perhaps, it may be inferred that Urioconium was built at the end of the first, or early in the succeeding century.

In an account of the Hypocaust found in 1788, I must refer to the Philosophical Transactions, No. 306, to Mr. Hartshorne's Salopia, and to plans and details given in the Archaeologia, vol, ix. p. 323. Mr. Dukes' MS. contains an

1 At the point where the ford crosses the river, just below the church, and whero the Watling Street is discernable, in a lane which points direct for the Stretton Hills, we find the remains pro. bably of a for't commanding the entrance of the city at that point, in the high mounds which still remain. Here, also, not far distant, was found in the river the capital of a column elegantly sculp. tured. On the northern side, where the city wall again leaves the river, the romains of a cut or canal, by which boats could be brought 1 p to the wall, may be discovered, just beyond Mr. Stauier's cottage, ou tho rond leading to Attingham. 
excellent drawing of the remains, and a full description. Mr. Blakeway states that the discovery occurred thus. Mr. Bennett, the occupier of the ficld to the north of the Old Wall, observing the sterility of a square plot about forty perches distant from the wall, determined to dig, and thereby discover the cause. As the ground was then unsown, they dug in a wrong place, and found only the foundations of old walls. But, as the inhabitants took advantage of the ground being opened to get out the stones, some of them at length came to the western corner of the unprofitable ground. Here they found a little door, about $2 \frac{1}{2}$ feet in height, which opened into a chamber 7 feet high by $9 \frac{1}{2}$ wide, it was ceiled over, and in perfect preservation. The Hypocaust seems to have been constructed with the materials of some former building, as is often found to be the case with Roman remains, the floor being supported by pillars of unequal length and dimensions, and the intervals being made up with tiles. The tesselated floors which have been found at Urioconium are very well given in Mr. Dukes' MS. One of the drawings, p. 67 , represents a floor found in 1734 ; the form is oblong, and semicircular at one extremity; it is composed of green, red, white, and blue tesseræ, the green forming the outside border. There are also representations of a square pavement found in 1706, and of another discovered in 1827, of oblong form, with a green border, the colours of the pattern being white and blue.

During the year 1854, some remains of a very interesting character were discovered in digging the foundations for some buildings in course of construction by the tenant Mr. Stanier. These consisted of four square bases with square columns upon them, distant from each other at regular intervals of $9 \mathrm{ft}$., thus forming a frontage of $36 \mathrm{ft}$., facing towards the Wrekin. They seem to have formed the portico of a temple or Basilica. On account of the remaining space being built upon, the excavation was not continued. The fold-yard occupies the spot where the building stood. Mr. Ashdown kindly communicated the following account to me,- "At the depth of 4 feet some old iron bars were discovered, which had evidently undergone the action of great heat; at a little further depth some remains of a lime floor, and broken urns were found lying upon it. In sinking the well, some oyster shells were raised from many feet below the level of the ground." 
In the year 1747, an account of some clay moulds, for forging Roman coin, including one with the head of Julia, wife of Severus, found at Wroxeter, was communicated to the Royal Society, which is published in the Philosophical Transactions. ${ }^{2}$ Four of the five moulds described were found in digging sand at Ryton, near Condover, five miles from Urioconium. They were all of the size of a denarius, and made of smooth brick clay. Great numbers of them were found, but for want of care were broken in pieces. ${ }^{3}$ Similar objects appear to have been previously found. On January 30, 1722, Mr. Price brought to the Society of Antiquaries two clay moulds for casting coins, found at Wroxeter, and then in possession of the Rev. Mr. Rawlins, the incumbent. One was for coins of Severus, the other of Plautilla, with reverses.

Before treating of the funeral inscriptions which have been found, I may mention that many urns have been discovered; also human skeletons deposited in red clay spread both over and under them, and covered over with thin slabs of stone, over which were heaped five or six larger stones and clay. Several sculls are said to have been found in hollows towards the Severn.

It does not appear that any stone coffins have been found similar to those discovered at York, Bath, Caerleon, and other Roman stations. Where stone was plentiful and more generally worked, the mode of burial seems to have corresponded with the locality and the material it afforded. I have mentioned that the site of the ancient burial-ground was, as is invariably the case, in Roman cities without the gates. The monuments discovered there are interesting. There is no account of any such relic found before September, 1752, when Mr. John Sias, in ploughing, struck upon a stone which lay with its face downwards, about 300 yards from the city wall on the N.E. side, towards the Watling Street. This stone is about 4 feet 5 inches high, and about 2 feet 3 inches wide. The upper part has the form of a pediment, with a pine cone rising from the apex, between two lions, in the middle of

- Vol. xliv. p. 557.

3 Seo Camden's Britannia, ed. Gough, vol. ir. p. 13; Salopia Antiqua, p, 118 .

- Two urns of unbaked clay, containing the ashes of bones reduced to powder, are now in the possession of Mr. Stanier:
They were found in the village; also a leaden sarcophagus, of small size, was exhibited in the Museum of the Institute at the Shrewsbury Meeting in 1855 . 'This little ossuarium contained calcined bones, and an earthen jar. 
the pediment is a rose. ${ }^{5}$ The inscription is as follows :C. MANNIVS C. F. POL - SECYNDVS - POLLEN $\cdot$ MIL LEG $\cdot$ XX. ANORV. LII. STIP. $\mathrm{XXXI} \cdot \mathrm{BEN} \cdot \mathrm{LEg} \cdot \mathrm{PR} \cdot \mathrm{H} \cdot \mathrm{s} \cdot \mathbf{E}$. It may be thus rendered :-Caius Mannius Secundus, son of Caius of Pollentum, a soldier of the twentieth legion, aged 52 years; having served 31 years in the legion, and being the benefciary of the principal legate. He rests here. Mr. Hartshorne has stated that Secundus and Pollens are titles of honour, bestowed by his general, but I am disposed to take a different view of the inscription.

Mr. Blakeway says of this monument, that the Vicar of Wroxeter, Mr. Cartwright, having read this inscription and having communicated intelligence of the discovery to some gentlemen in Shrewsbury, they determined to make a further search, and commenced boring the ground with spits; they thus brought to light two more stones not far from the first. With them fragments of urns were found, and a greyish dust apparently of ashes.

A second stone (found as stated), is to the memory of another soldier. The length is 4 feet 10 inches, and width 1 foot 9 .inches. Like the former it is formed with a pediment in which is a patera surrounded with foliage. The inscription is as follows :- $\mathrm{M} \cdot \operatorname{PETRONIVS} \cdot \mathrm{L} \cdot \mathrm{F} \cdot \mathrm{MEN}$. VIC . ANN $\cdot$ XXXVIII. MIL LEG $^{-}$XIIII $\cdot$ GEM $\cdot$ MILITAVIT ANN $\cdot$ XVIII. SIGN $\cdot \mathrm{FVIT}^{\cdot} \mathrm{H} \cdot \mathrm{S} \cdot \mathrm{E}$-Marcus Petronius, son of Lucius, of the tribe Menenia, lived thirty-eight years. $\mathrm{He}$ was a soldier of the fourteenth legion Gemina. He served eighteen years, and was standard-bearer. Here he rests.

A friend who has paid some attention to the History of the fourteenth Legion, and who is familiar with this inscription, says, _ " I feel certain that Petronius was a bearer of one of the signa of the fourteenth Legion in the famous victory over Boadicea, A.D. 61. This Legion arrived in Britain, A.D. 43, when Petronius being only twenty years old was a miles gregarius, and subsequently, for his valour perhaps under Ostorius Scapula, raised to the rank of Signifer. Being only thirty-eight when he died, the year of his death was probably A.D. 62. It could not have been

5 This, and the three following inscrip. tions, are preserved at the Grammar School, Shrewsbury, where they may be seen in the libiary. They are figured in Camden's Britannia, edit. Gough, vol. iii. p. 13. See also Hartshorne's Salopia Antiqua, p. 120, Phil. Trans, vol. xlix. tab. v. 
much later, for in A.D. 68 the fourteenth Legion was quartered in Dalmatia, (Tacitus). He may have died in consequence of his wounds in the year 61. At any rate this inscription is very interesting." If this conjecture be correct, we should be able to fix the first foundation of the Roman city Urioconium to the time of Ostorius.

The third is a slab 2 feet 8 inches high, and 2 feet 3 inches wide, divided into three compartments, two of which contain inscriptions, the vacant space being probably prepared for the memorial of the person who erected the monument, but whose name has never been inserted. The upper portion is ornamented by the figure of a head, on each side of which is a serpent, and on the side which is still entire, the figure of a dolphin, an ornament not unusual upon sepulchral slabs. This monument is to the wife and child of one, who doubtless at his death hoped to rest near to those who were dear to him while living, and caused a space to be left for his name and age at his decease.

\begin{tabular}{|c|c|}
\hline $\begin{array}{l}\text { D. M. } \\
\text { PLACIDA } \\
\text { AN } \cdot \text { LV } \\
\text { CVR } \cdot A C \\
\text { CONJ } \\
\text { X X X }\end{array}$ & $\begin{array}{l}\quad \text { D. M. } \\
\text { DEVCCV } \\
\mathrm{S}^{\cdot} \cdot \mathrm{AN} \cdot \mathrm{xV} \\
\text { CVRAC } \\
\text { PATRE }\end{array}$ \\
\hline
\end{tabular}

Three marks as shown above, are at the bottom of the first compartment, which has led to the supposition that Placida was thirty years married; they are however more probably merely an ornament, like a leaf introduced at the end of the next inscription.

A fourth sepulchral stone is the fragment of the memorial of a Thracian horseman, which like other sculptures of its class, displays a mounted warrior trampling on an enemy, as seen on a slab found at Watermore near Cirencester. Another example found at Bath is preserved in the museum of the Institution there. The slab at Wroxeter was found in a field about 200 yards N.E. of the city wall, and it was 
formerly placed against the wall of the vicarage, but is now lost. The inscription is as follows :-TIB CLAVD TIR : : NTIVS EQ $^{\circ}$ COH'THRACVM AN : : ORVM LVII. STI(P) ENDIOR 'x:X.H. S. (E), which may be rendered :-Tiberius Claudius Tirentius (according to $\mathrm{Mr}$. Blakeway, and Tirenius according to $\mathrm{Mr}$. Dukes) a soldier of the Thracian Cohort, who lived 57 years and served 20 , Here he rests. ${ }^{6}$

A fragment of another inscribed stone is described by Gough, in which may be traced the word MILEs. ${ }^{7}$ No mention of this slab is made by Mr. Hartshorne or Mr. Dukes. Gough says it lay at the side of the road under the wall of the last farm-house near the church.

Another fragment has lately been discovered, which is in the possession of the present vicar, the Rev. E. Egremont; it seems to be a portion of a mile-stone, and bears the letters CORN, and in the line below may be decyphered ALLIGN.

The only altar of which the discovery has been recorded, is one inscribed BONO REI PVBLICA NATVS. It is not mentioned by Mr. Hartshorne ; drawings of it are given both in Mr. Dukes' and Mr. Blakeway's collections. It had been found in the garden wall at the vicarage. ${ }^{8}$ The form is singular, being very broad in proportion to the height, and the top formed with a wide shallow focus, occupying nearly the whole of the surface. This altar exactly corresponds to the one in the Bath Literary Institution, found in 1753 with two others, at the lower end of Stall Street in that city. The Bath altar has occasioned discussion as to the special purpose for which it was intended. Mr. Warner ${ }^{1}$ conceives it was intended for offerings of herbs, fruits, and flowers; while Mr. Whitaker considers that the oblong focus contained the pan of coal, which is stated by Solinus to have been kept burning continually in the Temple of Minerva, who in all the Bath inscriptions is designated SUL-MINERVA. The inscription on the Bath altar is svLEvis SVLINVS - SCLVTOR · BRVCETI $F \cdot$ SACRVM F LM. The two first lines are in large letters, and appear to have been the

6 It is figured in Camden's Brit. ed. Gough, vol. iii. p. 23, edit. 1806 . Conpare the Watermore Sculptures, Archæo. logia, vol. xxvii., p. 212, plate 14 . See also the Asturian horseman on the slab at Cilurnum, Bruce's Roman Wall, p. 154.

$i$ It is fgured in Gough's Camden, vol. iii. p. 23.

- It is noticed by Mr. Roach Smith, Coll. Ant. rol. iii. p. 32, and has becn presented by Mr. Egremont to the Shrewsbury Museum.

1 Illustrations of Rom. Auticl. Found at Bath, p. 45. No. viii. 
original dedication; the rest is in smaller letters, and seems to have been added later. The Suleræ to whom this singular altar is dedicated, are supposed to have been the nymphs of the hot springs, the attendants on the goddess Sul. The coarse style of workmanship would lead us to assign it to a late period. The dedication on the altar found at Wroxeter oscurs in two inscriptions, as also on coins of Constantine, and this might lead us to infer that the period of its erection was during the reign of that emperor.

One of the most curious relics found at Wroxeter is a small stamp, such as were used by Roman empirics and ocularii; it is called by Mr. Hartshorne an "amuletal seal." 2 . In form it is unique, being circular, the others found in various parts of Europe being oblong. The dimensions and the inscription are here shown (see woodcut). The thickness of the stone is $\frac{7}{8}$ inch. It has been described as of jade, but it is of the

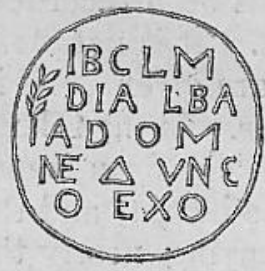
fine grained green schist, of which these stamps are usually formed. It was found in 1808 in ploughing near the "Old Wall," and it is now in the possession of Mr. Upton, of Atcham, near Shrewsbury, and was produced, with his permission, by the Rev. Mainwaring Owen at the Meeting of the Institute. A notice of this and of other empirics' stamps found in England has been given in this Journal by $\mathrm{Mr}$. Albert Way ; ${ }^{3}$ and a valuable memoir by Professor Simpson, of Edinburgh, will be found in the Monthly Journal of Medical Science.4 The following explanation of the inscription has been proposed, in extenso,-Julii Bassi Clementis Dialbanum ad omnem $\triangle \iota a \theta \epsilon \sigma \iota$ uno ex ovo," signifying, "The Dialbanum or Incense Collyrium of Julius Bassus Clemens, for every eye-disease, to be used mixed with egg." Dr. Simpson observes that the name of the practitioner or empiric, given in the first line of the seal, offers the principal difficulty in reading the inscription. The letters CLM. are probably a

2 Salopia Antiqua, p. 126. It was first noticed and figured in Gent. Mag., vol. lxxx.,p. 617. See also Beauties of England and Wales, Shropshire, p. 191.

3 Arch. Journal, vol. vii., p. 358.
4 Journal of Med. Science, 1851, p.235. See also Notes by tho Rev. J. McCaul, LL.D., President of Univ. Coll., T'oronto, read before the Cauadian Inst., Dec., 1857. 
contraction for Clemens. The $\mathrm{B}$. as an initial, may stand for many names, such as Bassus, Balbus, Betutius. It is here rendered Bassus, because on an old monumental tablet found at Leyden, the cognomen Clemens is preceded by the nomen gentilicium, Bassus; showing the combination not to have been unknown among the Roman colonists in Western Europe.

I will now notice certain remains of sculpture, bronze figures, and various relics found at Wroxeter. In 1730 there was discovered in a well a piece of sculpture, described as the naked figure of a boy leaning on a wand, and standing in an alcove. It was probably a figure of Mars leaning on a spear ; the left arm is imperfect, and may have borne a shield. The workmanship, as shown by the drawing in Mr. Dukes' MS., was good ; and it is to be regretted that this relic has not been preserved.

Numerous remains of an architectural character, carved stones, and broken columns, have been found at various times. In Mr. Dukes' MS. may be seen a drawing of a singular fragment, apparently of a column, sculptured with two human faces, the hands in each extending below the beard; this, however, I am inclined to regard as mediæval. It appears to resemble a corbel in Wells Cathedral, at the entrance of the choir. Some sculptured fragments of greater interest are still to be seen at Wroxeter, capitals of columns, one of them richly ornamented, obtained from the bed of the Severn, and two portions of a shaft, about 13 inches in diameter, sculptured with scales or leaf-ornament, and one part with crossed bands, in heraldic language, fretty. Mr. C. Roach Smith gives two plates of these curious fragments, in his Collectanea Antiqua. Examples of such columns, he observes, occur in Italy and in the south of France, but nothing similar has hitberto been found in this country. On one fragment is the lower part of a figure which he supposes to represent Atys; it may have represented Bacchus, with the panther. On the other appears a winged Cupid kneeling upon a pannier and holding bunches of grapes. ${ }^{4}$ These relics are now in the garden of Mr. W. H. Oatley. Mr. E. Stanier, the Duke of Cleveland's tenant, has the upper portion of the first-mentioned column ; it supplies the body and head of the figure attributed by Mr. Roach

${ }^{4}$ Collect. Ant., vol, iii. p. 30, pl, vi. viii.

YOL. IVI. 
Smith to Atys. It is to be regretted that these interesting fragments are thus disunited. Mr. Stanier possesses also some bases of columns, 33 inches in diameter, several urns, a fictile lamp ornamented with a figure of a lion, an alabaster lamp-stand, a fragment of Samian, marked IANVARI, and the rim of a mortarium with the potter's stamp, DociLis $\cdot F$. A number of quern-stones have been found, of which several 'remain in Mr. Stanier's garden. Many columns of various diameter have been dug up in the field behind Mr. Stanier's cottage, where the new field buildings stand; they have been split and used as coping stones for walls, one long wall being entirely thus covered, and these fragments have been chipped, to fit the size of the wall. It is stated that a considerable number of columns lay, when discovered, in rows, so that the general ground-plan of the building might doubtless have been traced.

In the Library of King Edward's Free Grammar School at Shrewsbury, various relics from Urioconium have been preserved with the inscriptions above noticed. Among these minor objects may be mentioned a fragment of tessellated pavement; two iron implements like pickaxes; a portion of leaden pipe; a fictile lamp ; bronze keys; a strigil, \&c. Also a fine bronze palstare, without the side-loop; a model of the hypocaust discovered in 1701, as related by Mr. Lyster in the Philosophical Transactions, may also there be seen.

In 1827 a bronze statuette of Apollo holding the lyre was found; a drawing is preserved among Mr. Dukes' collections, but the dimensions are not stated; and it is not known where this figure, apparently of good workmanship, now exists. A bronze figure of Diana and one of Mercury were discovered in 1848 ; they were reported to be in the possession of Mr. J. M. Forster, of Shrewsbury. A drawing of a bronze figure of a lion, found in 1820, may be seen in Mr. Dukes' MS.; and in 1818, some remarkable bronze fragments, supposed to be of armour, were brought to light. In the same collections are preserved drawings of various bronze ornaments, a stylus and a small spoon, a bronze stilyard in perfect preservation, and resembling that used at the present day, the introduction of which may date from Roman times. Personal ornaments, such as rings, buckles and fibula, are constantly brought to light, and for the most part fall into the hands of itinerant dealers, who visit the place in quest 
of such relics. Mr. Dukes has preserved drawings of numerous examples of Samian ware, including a bowl of remarkable size, also of beads, ornaments of glass and jet; and his MS. contains a detailed catalogue of coins, among which a single auveus is described ; it is a coin of Tiberius, with the reverse, Pontifex Maximus. The coins of silver, and brass, plated coins, \&c., are very numerous. They are locally called Dinders, a name possibly derived from the Roman Denarius. ${ }^{5}$ Dr. Stukeley related to the Society of Antiquaries, in 1725 , a story of a certain schoolmaster at Wroxeter, who was accustomed to send his boys to gather "Dinders, as they call Roman moneys," after a shower of rain, and he melted all the silver coins into a tankard. He also stated, in reference to the quantity of coins and relics found there, that the Lord of the Manor of Wroxeter, put a clause into his leases, that the tenants should bring in all antiquities found there, on pain of forfeiture of their leases ; and that a vast quantity of coins and other objects discovered there were brought to Ashmole, and had perished in the fire of London.

I cannot abstain from an expression of regret that no effort has hitherto been made to collect the relics of antiquity found at Wroxeter. In the old leases of the ground there was inserted a clause requiring that all objects of antiquity discovered, should be given up to the lord of the soil. ${ }^{6}$. If this care had also extended to providing a receptacle for them upon the site of the city, we should long since have had a local Museum of Roman remains, of very great interest; or, if a suitable depository had been provided in Shrewsbury, it would have been a great advantage to local history, and have presented an object of interest and instruction in a town which doubtless owes its origin, as Leland observed long ago, to the destruction of Urioconium. ${ }^{7}$ Caerleon presents a most praiseworthy example, in the valuable Museum of local antiquities which has there been recently formed, chiefly through the exertions of Mr. J. E. Lee. The great interest of such collections preserved near the site of their discovery, has been shown in a remarkable

${ }^{5}$ Horsley notices this local appellation. See also Mr. Hartshorne's Glossary of Shropshire Words, under Dinder. A catalogue of coins found at Wroxeter communicated by the Rev. F. Leighton, of Shrewsbury, may be found iu Gough's

Camden, vol. iii. p. 26, edit. 1806.

6 See Lloyd's MS. Hist. of Shropshire.

i Leland, Coll vol. iv. f. $181 \mathrm{~b}$. 
degree in the Museum formed at Cirencester by Professor Buckman, through the liberality of the Earl Bathurst.

Recent discoveries at Urioconium have given an earnest of what might still be there effected in times like the present, when the relics which throw light on our national history are more truly appreciated, and the improvements in agriculture by draining, or the operations of public works, are constantly bringing to light the vestiges of former times. The prophecy of Virgil has been fully realised,-

"Scilicet et tempus veniet, quum finibus illis

Agricola, incurvo terram molitus aratro,

Exesa inveniet scabra robigine pila,

Aut gravibus rastris galeas pulsabit inanis,

Grandiaque effossis mirabitur ossa sepulchris."

VIRGIL, Georg. lib. i. v. 493.

Since the visit of the Institute to Wroxeter, many remains have been disinterred; and a well organised movement has at length been made for the exploration of the site of Urioconium. During the past year a committee of the Shropshire Antiquarian Society has been formed, for the purpose of making excavations on an extensive scale; the object has been liberally promoted by their President, Beriah Botfield, Esq., M.P., and has met with much local encouragement. It is proposed that all antiquities discovered shall be placed in the Museum at Shrewsbury, and the sanction of the Duke of Cleveland, on whose estates Wroxeter is situated, having been obtained, this laudable undertaking has commenced, it may confidently be hoped under most favourable auspices. ${ }^{\mathrm{s}}$

HARRY M. SCARTH.

${ }^{8}$ It is very desirable that sufficient funds should be raised to car'y out 2 complete examination of the site of the city, an undertaking necessarily attended with considerable expenses. Contributions in aid of this interesting Archæo- logical enterprise are received by Henry Johnson, Esq., M.D., Secretary to tho Committee, Shrewsbury, from whom information and a Map of the site may be obtained. 